\title{
Effect of breed on food preference tests for dogs
}

\section{Efeito de raças em ensaios de preferência alimentar em cães}

\author{
Carolina Pedro Zanatta ${ }^{1}$; Diego Surek ${ }^{2}$; Larissa Wünsche Risolia ${ }^{1}$; Ananda Portella \\ Félix $^{3}$; Alex Maiorka ${ }^{3}$; Simone Gisele de Oliveira ${ }^{3 *}$
}

\begin{abstract}
This study aimed to determine the differences among four dog breeds as to food selectivity, choice agreement, and the number scores that best evaluate the degree of food choice agreement. For that, 115 food preference tests were analyzed. In each of those tests, 20 dogs were used (eight Beagles, four Labradors, four Siberian Huskies, and four Basset Hounds), in two evaluation days. The medians of intake difference between two diets were calculated for days one, two, and for both days to determine if there were selectivity difference among breeds. A randomized block experimental design was applied, and medians were submitted to the test of Friedmann. Food choice agreement and the degree of agreement among breeds were evaluated by the kappa index, using two different scales. Basset Hounds were the most selective when two different foods were offered, whereas Labradors were the least selective. When performing food preference tests, Siberian Huskies and Basset Hounds are recommended; however, they must be used individually to prevent that the results of one breed could neutralize those of the other breed. The use of a scale of food preference with three scores is recommended in order to obtain results that are more reliable.
\end{abstract}

Key words: Dog breeds. Food selection. Selectivity.

\section{Resumo}

Objetivando averiguar possíveis diferenças entre quatro raças de cães para concisão na escolha, concordância na preferência alimentar e número de escalas que melhor avalia a intensidade de concordância, foram avaliados 115 testes de preferência alimentar. Para cada teste foram usados 20 cães (oito Beagles, quatro Labradores, quatro Huskys Siberiano, e quatro Basset Hound) em dois dias de avaliação. Foram calculadas as medianas da diferença de consumo entre as duas rações no dia um, dois e no período total, para averiguar diferenças entre raças para concisão na escolha. O delineamento foi em blocos ao acaso e as medianas calculadas foram submetidas ao Teste de Friedmann. A análise de concordância e intensidade de concordância para preferência alimentar entre cada raça foi avaliada pelo Índice Kappa, por meio de duas escalas. Cães da raça Basset Hound foram os mais concisos na seleção quando na presença de mais de um alimento, enquanto Labradores foram os menos seletivos. Para delineamento de ensaios de preferência alimentar é indicado combinar as raças Husky Siberiano e Basset Hound, porém em testes separados, para evitar que uma anule a outra. Para aferição dos resultados é aconselhada a utilização de três escalas, a fim de se obter resultados mais confiáveis.

Palavras-chave: Seleção de alimentos. Raças de cães. Concisão de escolha.

1 Discente, Programa de Pós-Graduação em Ciências Veterinárias, Universidade Federal do Paraná, UFPR, Curitiba, PR, Brasil. E-mail: carol.zanatta@zootecnista.com.br; larissa.risolia@gmail.com

2 Analista, Empresa Brasileira de Pesquisa Agropecuária, EMBRAPA, Centro Nacional de Pesquisa de Suínos e Aves, Concórdia, SC, Brasil. E-mail: diego.surek@embrapa.br

3 Profs., Departamento de Zootecnia, UFPR, Curitiba, PR, Brasil. E-mail: apfelix@ufpr.br; amaiorka@ufpr.br; sgoliveira@ufpr.br

* Author for correspondence

Received: Oct. 21, 2016 Approved: Mar. 31, 2017 


\section{Introduction}

Food preference trials are extremely important to determine the factors that affect food preference in dogs. Food preference is the act of choosing or favoring one food source over another, which is a manifestation of distinction. This preference for one food item over the other is intrinsically linked to the palatability of both food sources. Palatability is defined as the set of physical-chemical characteristics of foods, such as flavor, texture, and odor, which cause a pleasant physiological sensation, being the food recognized as tasty and pleasurable to be consumed (FÉLIX et al., 2010). Meanwhile, the food preference is the result of a test evaluating, by comparison, the most palatable food for a certain group of animals. In this sense, the choice of dog breed is crucial to obtain reliable results, as dogs from different breeds present behavioral differences, including ingestive behaviors. Unfortunately, there are no studies in the literature referring to palatability tests comparing different breeds.

Intake behavior characteristics vary according to breed. This is due to the exacerbated appetite which some breeds present and, when these animals are fed at will, may develop obesity (SAAD; SAAD, 2004; RAMOS et al., 2016). It has been found that Labradors can ingest on average 20\% more energy, meanwhile, Siberian Husky dogs can consume up to $35 \%$ less. For Beagles, voluntary energy consumption is close to the recommendations of the National Research Council - NRC (2006) (RAMOS et al., 2016).

According to Felix (2010), the senses present hierarchies of importance in the perception of palatability, and for dogs, the main is the sense of smell, followed by taste and touch (mouthfeel). With regard to smell, the olfactory acuity of animals may vary according to the breed of the dog. This occurs because of factors such as olfactory mucosal surface, the number of olfactory cells, and facial anatomy (FÉLIX et al., 2010). Thus, the anatomical characteristics of different breeds may interfere with the preference of a particular food. Of course, there are factors unique to each individual; however, the anatomical-physiological characteristics of each breed interfere, in a similar way, with these individual effects. Thus, it is noted that different breeds instinctively have a different stimulus to food consumption, which must be respected when performing palatability tests.

Breeds can be more or less selective when choosing food, presenting greater conviction in the choice, what is called selectivity (FÉLIX et al., 2010). Food selectivity is the act or effect of selecting a food and is based on a well-founded choice. Thus, animals that are more selective might be used in food preference tests. Also, dogs from different breeds may prefer different diets, that is, dogs belonging to breed A may prefer $\operatorname{diet} A$, whereas dogs from breed B may prefer diet B. Therefore, when assessing diet preference of dogs, we propose the term 'agreement of choice'. Another parameter that may aid in the evaluation of food preference and complement agreement of choice results is the degree of agreement, which is measured by the kappa index (SIEGEL; CASTELLAN, 1988). Using value ranges, which vary from no agreement to complete agreement, this test is to indicate how much the animals agreed in terms of food choice.

Currently, as there is little information available, food preference tests lack scientific validity and standard protocols. Therefore, this study aimed to compare food selectivity, food preference agreement, and a number of scales that best evaluate the degree of food preference agreement for four breeds of dogs.

\section{Materials and Methods}

The Ethics Committee on Animal Use approved this experiment, under protocol number 027/ 2011,by the Agricultural Sciences Sector, Federal University of Paraná, on October 14, 2011.

Data obtained from 115 food preference tests were evaluated. These trials were performed to compare different food flavors, being carried out in 
a commercial kennel between 2009 and 2012. The tests were performed always with the same dogs, which belonged to four different breeds (Beagle, Labrador, Siberian Husky, and Basset Hound).

Two diets were offered (diets A and B). The diets contained the same nutritional composition, except for flavor. The palatability agents used in this study were commercial products different from each other. These agents were added to the diets at an equal level. All tests were carried out with the above-mentioned four breeds, at a proportion of 0.75 females and 0.25 males. Twenty dogs were tested: eight Beagles, four Labradors, four Siberian Huskies, and four Basset Hounds. The mean weight of animals per breed was Labrador $(27.2+2.8 \mathrm{~kg})$, Beagle $(13.1+1.2 \mathrm{~kg})$, Basset hound $(22.8+1.9$ $\mathrm{kg})$, and Siberian Husky $(21.8 \pm 2.3 \mathrm{~kg})$;yet the ages, regardless of race, were between $3 \pm 0.8$ years. Dogs were housed in individual kennels. All dogs were adults and had been previously vaccinated, dewormed, and clinically evaluated.

Foods were always offered at 18:00 o'clock and the water supply was ad libitum. The tests were performed every two consecutive days. This was done to make the sample more statistically significant (minimum 16 replicates) since it is very difficult to have a large number of animals to participate in the tests. In addition, the individual intrinsic effect of animals increases the variability of the test results, making it necessary to increase the number of repetitions, which was done on the second day. Finally, by repeating the test, it was possible to ensure that the bowl site had no interference with the result since they had their position inverted on the second test day. Diets were simultaneously offered in identical stainless steel bowls, previously identified, changing their position within the kennels at each meal in order to prevent habituating dogs to the same position of the bowl. For each test day, the number of bowls was twice the number of dogs, (one for $\operatorname{diet} \mathrm{A}$ and one for diet B), so that the animals used different bowls during the test day. Diet A bowls were always used to serve this diet, so were diet B bowls. After each test, food bowls were sanitized with water and soap. There was no period of adaptation of the dogs to the diets. The tested diet was calculated to supply the metabolizable energy requirements (MER) of dogs, being estimated according to the following equation: MER $=130 \mathrm{x}$ body weight 0.75 , as recommended by the NRC (2006), plus 0.3.

The dogs had access to the foods for $30 \mathrm{~min}$, receiving no other type of food during the day. Both food bowls were removed if one of the foods was completely consumed before the 30-min period ended. The intake of each food was calculated using the data from the spreadsheets of the 115 food preference tests above-mentioned. The spreadsheets contained daily data on food allowance and on the residues of diets $\mathrm{A}$ and $\mathrm{B}$ per individual animal, allowing the calculation of food intake. Data relative to two test days were evaluated. Food intake data were used to calculate intake ratio (IR) for both days, according to the following equations:

$\mathrm{IRA}=[$ intake of $\operatorname{diet} \mathrm{A} /($ intake $\operatorname{of} \operatorname{diet} \mathrm{A}+$ intake of $\operatorname{diet} \mathrm{B})]^{*} 100$ for $\operatorname{diet} \mathrm{A}$

$\mathrm{IRB}=100-$ IRA for diet $\mathrm{B}$

The difference between IRA and IRB was then calculated. The IRA, IRB, and IRA to IRB difference were calculated for both evaluation days. Subsequently, IRA and IRA mean values were calculated for a total intake of the respective diets, as well as their difference (IRAtot - IRBtot). Using the individual values obtained from IRA - IRB day 1 (food intake difference on day 1; ID1), IRA IRB day 2 (food intake difference on day 2; ID2), and IRAtot - IRBtot (total intake difference; TID), medians were calculated and grouped per breed (four breeds) for each test (115 tests), totaling four medians per test. The comparison among medians resulted in the parameter called selectivity.

Medians were analyzed according to a randomized block design. The medians calculated for ID1, ID2, and IDT were submitted to ShapiroWilk's normality test, without meeting the 
homoscedasticity assumption. Therefore, the medians were submitted to the test of Friedmann to verify if there were differences among the races in terms of food selectivity. The test of Friedmann is a statistical test for non-parametric data distributed in a block experimental design. In this case, the dog breeds (Labrador, Siberian Husky, Basset Hound, and Beagle) were used as treatments, and food preference tests were used as blocks. Data were analyzed using SAS statistical package (SAS Inst. Inc., Cary, NC). It should be stressed that low values indicate lower diet selectivity. On the other hand, high values are no indication of the same food preference by different breeds but one breed may prefer $\operatorname{diet} \mathrm{A}$ to Band another $\operatorname{diet} \mathrm{B}$ to $\mathrm{A}$.

In order to determine if there was any agreement in food preference among breeds, the kappa index was calculated. This test is also called "interjudge" or "inter-observer" agreement and aims at determining whether two or more judges (breeds, in the present study) agreed on the same response, i.e. the number of evaluations with the same result among judges. In the case of the present study, it refers to the number of times the different breeds chose the same food. The $\mathrm{P}$-value and $\mathrm{P}<0.01$ indicate the agreement in response.

The kappa index also evaluates the degree of food preference agreement, that is, it indicates how much the evaluated breeds agreed on food choice. A kappa index of 1 means a perfect agreement, whereas values close or below zero indicate that agreement differs. Negative values merely indicate that there is no agreement of choice, with no degree of agreement (BALTAR; OKANO, 2012).

Therefore, in order to evaluate the agreement, the medians of choices for diets $A$ and $B$ of the respective breeds were transformed into scores, and a kappa index was generated (SIEGEL; CASTELLAN, 1988). It must be noted that the greater the number of scores, the stricter the comparisons, which may prevent the detection of the desired results. The two methodologies were then used to classify food preference agreement: one with two and the other with three scores.

In order to analyze agreement among breeds, each median of the intake values for each animal in the evaluated periods (day 1, day 2, and total period) was scored according to a 3-score scale of preference $(1,2$, or 3$)$. The scale worked as follows: score 1: $<0.4$ of the dogs preferred $\operatorname{diet} \mathrm{A}$; score 2: $\geq 0.4$ no preference $<0.6$; score $3:>0.6$ of the dogs preferred diet B. Alternatively, a 2-score scale of preference was used, with score 1 when $\leq 0.5$ of the dogs preferred diet A, and score 2 when $>0.51$ of the dogs preferred diet B. The medians scored in each scale were submitted to the kappa analysis at 0.01 probability level using SAS statistical package (SAS Inst. Inc., Cary, NC).

Breeds were pairwise compared, and the degree of agreement was evaluated according to the study of Landis and Koch (1977), in which the degree of agreement is attributed to a corresponding interval (Table 1).

Table 1.Degree of agreement attributed to the corresponding kappa value interval.

\begin{tabular}{cc}
\hline Kappa values & Degree \\
\hline$<0$ & No agreement \\
$0-0.19$ & Weak agreement \\
$0.20-0.39$ & Reasonable agreement \\
$0.40-0.59$ & Moderate agreement \\
$0.60-0.79$ & Substantial agreement \\
$0.80-1.00$ & Almost perfect agreement \\
\hline
\end{tabular}

Adapted from Landis and Koch (1977). 


\section{Results and Discussion}

Table 2 shows the median of each breed for diet 1, diet 2, and total intakes (ID1, ID2, IDT), which represent diet selectivity by the dogs. In general, the range of selectivity differences among breeds was different for each diet and period $(\mathrm{P}<0.05)$.

Table 2. Agreement of choice of the dog breeds used in palatability tests.

\begin{tabular}{lccc}
\hline \multirow{2}{*}{ Breeds } & \multicolumn{3}{c}{ Days } \\
\cline { 2 - 4 } & ID1 $(\mathbf{g})$ & ID2 $(\mathbf{g})$ & IDT $(\mathbf{g})$ \\
\hline Beagle & $44.231^{\mathrm{ab}}$ & $46.528^{\mathrm{a}}$ & $44.813^{\mathrm{b}}$ \\
Labrador & $22.074^{\mathrm{c}}$ & $23.218^{\mathrm{b}}$ & $22.783^{\mathrm{c}}$ \\
Siberian Husky & $40.278^{\mathrm{b}}$ & $43.417^{\mathrm{a}}$ & $38.915^{\mathrm{b}}$ \\
Basset Hound & $50.395^{\mathrm{a}}$ & $49.612^{\mathrm{a}}$ & $51.590^{\mathrm{a}}$ \\
Friedman & 104.78 & 88.763 & 108.76 \\
$\mathrm{P}$ & $<0.001$ & $<0.001$ & $<0.001$ \\
\hline
\end{tabular}

P: probability

ID1: intake difference on day 1, ID2: intake difference on day 2, IDT: intake difference in the total period Medians followed by the same superscript in the same column show no difference by the Friedman's test ( $\mathrm{P}>0.05)$.

Beagles have a lot of stamina, run at high speeds, and are docile to humans. Their sense of smell is highly developed, and they are very determined, which makes them good hunting dogs. Basset Hounds are calm and stubborn, and, despite their excellent sense of smell, they may refuse to hunt. Labradors are excellent hunters due to their outstanding sense of smell, and persistency when chasing the prey. They are voracious and because of their playful behavior, they should be trained early in life. Siberian Huskies originate from North Siberia, which was bred to pull sleds sine they are very resistant to work and low temperatures. However, they are very independent, which may interfere with training. They are also good hunters, in addition to being obstinate and agile (FÉLIX et al., 2010; PERES, 2010).

Such behavioral differences affect the ingestive behavior of these breeds, as shown by the observed diet selectivity. Labradors were the least selective, whereas Basset Hounds were the most selective ones. In other words, Basset Hounds were more cautious when choosing a different diet. This may be explained by the results obtained by Capiola and Raudenbush (2012), who evaluated ingestive behavior in humans and found that, depending on previous experiences, humans may be neophobic, i.e., were aversive to new foods with lower food ingestion compared with neophilic people, who are attracted to new foods.

Beagles were as selective as Basset Hounds in two of the three evaluated periods and presented the same selectivity as Siberian Huskies in the three periods. This suggests that Beagles and Siberian Huskies present the same food selectivity.

It was also observed that, on the second day, the selectivity values for Beagles and Siberian Huskies were closer than were those obtained on the first day, i.e., there was less variation, indicating greater selectivity. This may be because of the contact with the food, on the previous day, enhanced selectivity, despite the change in the position of the bowls. On the other hand, Labradors showed no selectivity in any of the evaluated periods, probably due to their voracious eating behavior. 
Comparing the ingestive behavior of different dog breeds, Ramos et al. (2010) observed that, as recommended by the National Research Council (NRC, 2006), Labradors may ingest, in average, 0.2 more energy, and Siberian Huskies 0.35 less energy, whereas voluntary energy intake of Beagles is close to the recommendations. Saad and Saad (2004) also observed that Labradors had higher metabolizable energy intake per $\mathrm{kg}$ metabolic weight than did Beagles, again possibly due to the avid appetite of the former.

Table 3 shows the degree of agreement among breeds when using the 3 -score scale of preference.

Table 3. Agreement of choice between two foods among breeds using a 3-score preference scale (kappa index).

\begin{tabular}{lllc}
\hline Breeds & day 1 & day 2 & TP \\
\hline Beagle x Labrador & 0.1689 & 0.1790 & 0.1633 \\
P & 0.0103 & 0.0068 & 0.0102 \\
Beagle x Siberian Husky & 0.2668 & 0.1797 & 0.2448 \\
P & $<.0001$ & 0.0069 & 0.0002 \\
Beagle x Basset Hound & 0.1731 & 0.1814 & 0.1294 \\
P & 0.0079 & 0.0055 & 0.0514 \\
Labrador x Siberian Husky & 0.0380 & 0.2029 & 0.1355 \\
P & 0.5534 & 0.0014 & 0.0203 \\
Labrador x Basset Hound & 0.0767 & 0.1772 & 0.1239 \\
P & 0.1997 & 0.0036 & 0.0400 \\
Siberian Husky x Basset Hound & 0.0686 & 0.1298 & 0.0129 \\
P & 0.2988 & 0.0498 & 0.8450 \\
\hline
\end{tabular}

P: probability

day 1: period 1; day 2: period 2; TP: total period. The agreement of choice among the breeds evaluated by the Kappa test $(\mathrm{P}<0.01)$.

Beagles and Siberian Huskies agreed on their food choice in the three evaluated periods but the degree of agreement was weak to reasonable $(\mathrm{P}<0.01)$. In addition, the selectivity of these two breeds was similar, as shown in Table 2, demonstrating that both of them were selective and agreed on their food choice. Beagles also agreed with Labradors and Basset Hounds but on fewer days and to a weaker degree.

Labradors agreed with the other three evaluated breeds but only on the second day and weakly $(\mathrm{P}<0.01)$. Differently from Beagles, Labradors showed no food selectivity, which may justify their agreement of choice with the other breeds. The only breed combination showing no agreement was
Basset Hound and Siberian Husky $(\mathrm{P}>0.01)$. Basset Hounds showed the greatest degree of preference for a diet, and Huskies, the lowest, confirming that these breeds have different food preferences.

These results suggest that some breeds are better than are others for food preference tests, depending on the objective of the test. Breed combinations could also be used. According to the results of the present experiment, regarding the similarity in food selectivity and agreement of choice, Beagles and Siberian Huskies could be used in tests comparing food sources for specific dog sizes or breeds. In this case, breeds with a different agreement of choices are unadvisable, as one breed could neutralize the results of the other. 
Another combination may be between Beagles and Basset Hounds, as they also present agreement of choice at a high degree. Despite also showing an agreement of choice, Labradors are unsuitable for food preference tests because of their low food selectivity, which may lead to misinterpretation of the results. On the other hand, Basset Hounds are the most indicated, as they present a standard selectivity, and their acceptance of a determined food could be extrapolated to other breeds.

When comparing foods with subtle differences, i.e., foods with similar quality, the use of breeds with disagreeing food choices may be useful and efficient. In this case, Siberian Huskies and Basset Hounds could be used, as both are quite selective. However, they should be used in individual tests, as the results of one breed may neutralize the results of the other.

Therefore, when performing palatability tests, breeds presenting agreement of choice should be used when the objective is to evaluate foods with specific characteristics, whereas breeds with no agreement of choice in tests comparing foods with similar quality. The use of more than one breed may increase the reliability of the results. Yet, Labradors must be used with caution, as they are less selective.

Another interesting finding of the present experiment was a high agreement among breeds on the second evaluation day compared with the first, except for the lack of agreement of choice between Basset Hounds and Siberian Huskies. This high agreement might be explained by the fact that the dogs had had contact with the diet on the first day and, therefore, already knew the food sources offered on the second day, making the choice easier.

Table 4 presents the agreement of choice and the degree of agreement according to breed when the 2-score scale of preference was applied.

Table 4. Agreement of choice between two foods among breeds using a 2-score preference scale (kappa index).

\begin{tabular}{lllc}
\hline Breeds & day 1 & day 2 & TP \\
\hline Beagle x Labrador & 0.2746 & 0.3240 & 0.3295 \\
P & 0.0028 & 0.0005 & 0.0003 \\
Beagle x Siberian Husky & 0.3395 & 0.4218 & 0.4399 \\
P & 0.0003 & $<.0001$ & $<.0001$ \\
Beagle x Basset Hound & 0.3521 & 0.2465 & 0.2493 \\
P & 0.0002 & 0.0082 & 0.0075 \\
Labrador x Siberian Husky & 0.4081 & 0.3419 & 0.3587 \\
P & $<.0001$ & 0.0002 & 0.0001 \\
Labrador x Basset Hound & 0.1242 & 0.0994 & 0.0227 \\
P & 0.1717 & 0.2818 & 0.8014 \\
Siberian Husky x Basset Hound & 0.2182 & -0.0180 & 0.0884 \\
P & 0.0184 & 0.8469 & 0.3383 \\
\hline
\end{tabular}

P: probability

day 1: period 1; day 2: period 2; TP: total period. The agreement of choice among the breeds evaluated by the kappa test $(\mathrm{P}<0.01)$.

By reducing from three to two scores, the number of breed combinations agreeing on their choice increased on all evaluated days (Table 4), while when three scores were used, only one breed combination 
(Beagle $\mathrm{x}$ Siberian Husky) presented agreement of choice $(\mathrm{P}<0.01)$. In the 3 -score scale, selectivity classification was more precise: dogs could choose $\operatorname{diet} \mathrm{A}$, diet $\mathrm{B}$, or none of them. However, in the 2-score scale, the score "no preference" is disregarded, i.e., dogs were classified only relative to the selection of diets A or B, selecting broadly and increasing the number of agreements, which may lead to misinterpretation of results.

Using the 3-score scale, the only combination showing no agreement of choice was Basset Hound and Siberian Husky $(\mathrm{P}>0.01)$; while using the 2-score scale, Basset Hounds also presented no agreement of choice with Labradors. This contrast is justified by the fact that if the intake of one breed had been lower than 0.4 , for instance, this breed would have been classified as selective for $\operatorname{diet} \mathrm{A}$ in both scales. However, breeds consuming 0.4-0.5 were scored as "no preference" in the 3 -score scale and as "preference for diet A" in the two-score scale (Table $5)$. Therefore, the 3 -score scale seems to be more effective in classifying breeds according to food selectivity, providing results that are more reliable.

Table 5. One exampleof the 115 tests evaluated for food intake by different breeds and the respective preference classification.

\begin{tabular}{lccc}
\hline Breeds & Food intake $(\mathbf{g})^{*}$ & 2 scores & 3 scores \\
\hline Beagle & 45.08 & Diet A & No preference \\
Labrador & 48.72 & Diet A & No preference \\
Siberian Husky & 62.59 & Diet B & Diet B \\
Basset Hound & 52.37 & Diet B & No preference \\
\hline
\end{tabular}

* Values derived from the medians of intake difference on day 1 (ID1).

\section{Conclusions}

Basset Hounds were the most selective when two different food sources were offered, whereas Labradors were the least selective ones. When performing food preference tests, Siberian Huskies, Basset Hounds, and Beagles are recommended; however, they must be used individually to prevent that the results of one breed neutralize those of the other. The use of a food preference scale with three scores is recommended to obtain results that are more reliable.

\section{References}

BALTAR, V.T.; OKANO, V. Análise de concordância. São Paulo: Kappa. Laboratório de Epidemiologia e Estatística, 2012. Available at: $<$ http://www.lee.dante.br/ pesquisa/kappa/index.html >. Accessed at:12 aug. 2013.
CAPIOLA, A.; RAUDENBUSH, B. The effects of food neophobia and food neophilia on diet and metabolic processing. Food Nutrition Science, New York, v. 3, n. 10, p.1397-1403, 2012.

FÉLIX, A. P.; OLIVEIRA, S. G.; MAIORKA, A. Fatores que interferem no consumo de alimentos em cães e gatos. In: VIEIRA, S. L. (Ed.). Consumo e preferência alimentar de animais domésticos. Londrina: Phytobiotics, 2010. cap. 3, p. 162-199.

LANDIS, J. R.; KOCH, G. G. The measurement of observer agreement for categorical. International Biometric Society, Washington, v. 33, n. 1, p. 159-174, 1977.

NATIONAL RESEARCH COUNCIL - NRC. Nutrient requirements of dogs and cats. Washington: National Academic Press, 2006. 424 p.

PERES, M. N. Larousse do cão e do cãozinho. São Paulo: Larousse Brasil, 2010. 384 p.

RAMOS, T. A.; RISOLIA, L. W.; OLIVEIRA, S. G. de; FÉLIX, A. P.; BRITO, C. B. M. de; MAIORKA, A. 
Consumo voluntário de energia por cães de diferentes raças. Archives of Veterinary Science, Curitiba, v. 21, n. 1, p. 77-81, 2016.

SAAD, F. M. O. B.; SAAD, C. E. P. História evolutiva na alimentação e controle de consumo dos cães e gatos. 2004. Monografia (Trabalho de Conclusão de Curso de
Especialização em Nutrição e Alimentação de Cães e Gato) - Universidade Federal de Lavras, Lavras.

SIEGEL S.; CASTELLAN, N. Nonparametric statistics for the behavioral sciences. $2^{\text {th }}$ ed. New York: McGrawHill, 1988. $422 \mathrm{p}$. 
